\title{
The journey of rheumatoid arthritis patients: a review of reported lag times from the onset of symptoms
}

\author{
Alaa S Barhamain' \\ Rami F Magliah' \\ Mohammad H Shaheen' \\ Shurooq F Munassar' \\ Ayman M Falemban' \\ Mohammed M Alshareef' \\ Hani M Almoallim ${ }^{1-3}$ \\ 'Department of Medicine, Faculty of \\ Medicine, ${ }^{2}$ Alzaidi Chair of Research \\ in Rheumatic Diseases, Umm Alqura \\ University, Makkah, ${ }^{3}$ Department \\ of Medicine, Dr Soleiman Fakeeh \\ Hospital, Jeddah, Saudi Arabia
}

This article was published in the following Dove Press journal: Open Access Rheumatology: Research and Reviews 28 July 2017

Number of times this article has been viewed

Background: Even after achieving tremendous advances in diagnosis and treatment of rheumatoid arthritis (RA), many of the patients undergo delays in diagnosis and initiation of treatment, which leads to worsening of the condition and poor prognosis.

Objective: The objective of this study was to perform a literature review to quantify the lag times in diagnosis and treatment of RA and study the reported factors associated with it.

Methods: The authors searched literature published until September 2016 in electronic full-text and abstract databases and hand-searched the suitable articles.

Results: The weighted average of median lag time from symptom onset to therapy was 11.79 months (12 studies, 5,512 patients, range 3.6-24.0 months). Lag1 was 3.14 months (onset of symptoms to first physician consultant; 12 studies, 6,055 patients, range 0-5.7 months); lag2 was 2.13 months (physician visit to RA specialist referral; 13 studies, 34,767 patients, range 0.5-6.6 months); lag3 was 2.91 months (consultation with rheumatologist to diagnosis; 3 studies, 563 patients, range $0-5$ months), lag4 was 2.14 months (diagnosis to initiation of disease-modifying antirheumatic drug therapy; 5 studies, 30,685 patients, range 0-2.2 months). Numerous patientand physician-related factors like gender, ethnicity, primary care physician knowledge of the condition, availability of diagnostics, and so on were responsible for the delays.

Conclusion: This review estimated the delay times and identified the main factors for delay in RA patients in diagnosis and initiation of treatment. A most plausible solution to this is coordinated effort by the rheumatology and primary care physicians.

Keywords: arthritis, rheumatoid, rheumatologists, lag time, delay, diagnosis, disease management

\section{Introduction}

Rheumatoid arthritis (RA) follows a chronic course and invariably involves significant long-term disability and morbidity. ${ }^{1,2} \mathrm{~A}$ diverse group of agents called disease-modifying antirheumatic drugs (DMARDs) and potent anti-inflammatory antibodies that block tumor necrosis factor are widely accepted, respectively, for slowing the progression of RA and alleviating the painful symptoms. ${ }^{3,4}$ Though clinically effective, these drugs become less effective in halting the long-term progression of RA if initiation of therapy is delayed.,5 After onset of the symptoms, the disease progresses quickly leading to irreversible cartilage damage in $<2$ months. $^{7}$ This damage can only be prevented by the initiation of therapy within 2 months from the onset of symptoms. ${ }^{7}$ Initial studies reported no such benefit; ${ }^{8}$ however, carefully designed subsequent studies have established that patients in the earliest stages respond better to treatment compared to patients with long-established disease. ${ }^{8,9}$

With empirical evidence supporting early initiation of therapy in RA patients, it becomes necessary to minimize the lag time between the initiation of symptoms and
Correspondence: Hani M Almoallim Department of Medicine, Umm Alqura University, PO Box I82I, Jeddah 2I44I, Saudi Arabia

Email hmmoallim@uqu.edu.sa 
therapy. ${ }^{10}$ Unfortunately, the early stages of RA are characterized by nonspecific clinical signs that have been a frequent hurdle in timely initiation of the therapy. ${ }^{11}$ A large study of 488 patients during 1950-1974 had shown that there was a median lag of 6 months between the onset of symptoms and diagnosis. ${ }^{12}$ This has not improved even during the 1990s as 5 months lag between the onset of symptoms and diagnosis was very common. ${ }^{13}$ Furthermore, some of the patients remain untreated for up to 10 years after the symptoms appear. ${ }^{13}$

A recent study performed in Saudi Arabia found that patients consulted an average of 4 physicians between their first symptom of RA and final diagnosis, with a mean time from the first physician visit to final RA diagnosis of $\sim 30$ months. ${ }^{14}$ Although patients consulted with physicians at a mean of 7 months after the onset of RA symptoms, very few subjects initially sought a consultation with rheumatologists, who were ultimately responsible for diagnosing most RA patients.

Like any other disease, the RA patient's journey involves 3 distinct stages: onset of symptoms to consultation (lag1), consultation to rheumatology referral or definite RA diagnosis (lag2), and diagnosis to proper treatment (lag3). These lag times have been of interest to rheumatologists and have been reported by numerous studies ${ }^{15,16}$ with some studies focusing specifically on the factors that contribute to these delays and measures undertaken to overcome these.

In this review, we examined the literature to study the lag times in RA patients with an aim to summarize the findings for future reference. Further analysis of factors was also undertaken to understand the reasons for these lags.

\section{Methods}

The primary objective of this study was to review the reported delay in the duration (lag time) between symptom onset and initial physician visit, an initial visit to rheumatology referral, referral to diagnosis and diagnosis to proper treatment.

Secondary objectives are to review the significance of reported factors that may have contributed to delayed RA diagnosis, and the possible measures that could be taken to accelerate RA diagnosis and early initiation of treatment.

A systematic search of OVID and PubMed databases was conducted in March 2016 to identify all the data related to the journey of RA patients. In addition, Annals of Rheumatic Diseases, American College of Rheumatology Conference Index, and European League Against Rheumatism Conference Index were searched for relevant abstracts that are not published elsewhere.
The following keywords were used in the search for literature: [time lag, delay, duration] between [onset of symptoms of rheumatoid arthritis] and [presentation to/encounter/ consult] of [a physician/rheumatologist]. In addition, we searched: [time lag, delay, duration] between [onset of symptoms of rheumatoid arthritis] and [initiation antirheumatic drugs]. All the search terms were "exploded" in conjunction with using a keyword search. The search was conducted on March 31, 2016, and was limited to English language papers.

Included databases were distributed among authors and were searched independently using the above keywords. In each database, all the search results were reviewed and papers were checked for their relevance to our primary and secondary objectives based on their title, abstract, and manuscript. Papers that were not related to our objectives were excluded primarily. After the first round of work, databases were switched among authors to ensure accuracy of literature search and selection. Disagreements were settled through discussion between the authors. The studies were subjected to 3-phase selection. Titles were screened in the first round, abstracts in the second round, and full-texts in the third round. The most recent study was considered in the case of duplicate or overlapping population studies.

Studies were eligible for inclusion if they contained original data on number of patients, lag between the onset of symptoms and first physician visit or lag between initial visit and rheumatology referral, or lag from referral to diagnosis and/or lag from diagnosis to the initiation of DMARDs. Papers analyzing the significance of factors contributing to these lags in RA patients were selected toward the secondary objective of this review. Studies satisfying the above criteria were eligible for inclusion, irrespective of demographic, geographic, or design variations.

Lag times were not reported uniformly among papers. For example, some considered lag 1 as the time from onset to first medical encounter while others considered it as the time from first medical encounter until referral to rheumatologist, and so on. Many studies reported a single time lag (eg, from onset to diagnosis) and provided no further details. Some studies reported lag time in weeks and others in months. Some articles compared the results of 2 or more studies that were performed under similar settings but in 2 different time periods followed by comparison of lag times. Descriptive presentation also varied as some studies reported lag time as averages while others reported the median values. Except for the mean and median issue, we resolved other issues by setting our own definitions of lag times, namely lag 1 as the time from onset of symptoms to seeking first medical consul- 
tation; lag2 as time from seeking medical consultation until referral to rheumatologist; lag3 as the time from referral to definite RA diagnosis, and lag4 as the time from diagnosis to the initiation of DMARDs.

If detailed lag times were not reported in any study, but only a single lag time with a specific start and end points, cells in the corresponding row on the table were merged according to the start and end points specified in that study. We used months as time unit uniformly. Whenever the lag times were reported in weeks and days, we converted them into months. In the case of comparative studies, we only reported data from the latest studies.

For the mean and median issue, when calculating the total lag time, we included only studies that had reported the delay in mean and SD value in the calculation of the total lag times.

\section{Results and discussion}

The initial literature search returned 363 titles. After screening of titles for eliminating duplicates and irrelevant studies, we were left with 150 studies. Ninety-five studies were eliminated in the next stage after abstract and full-text screening (Figure 1). Out of these, 37 studies were relevant to 1 or multiple variables of our primary objective, and 18 studies were relevant to our secondary objective. Data from these papers were extracted and reviewed.
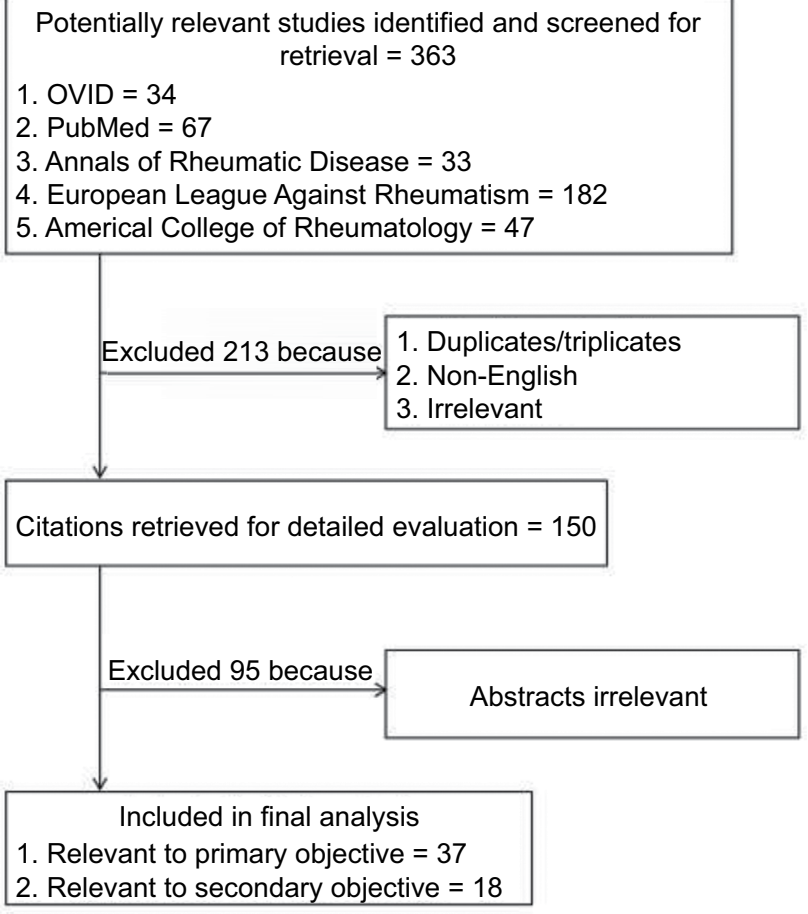

Figure I Flow diagram of study selection.
The full-text papers from the first and second category were reviewed. Studies that were only available as informative abstracts were included if complete data on the number of subjects and lag time were provided, even if published in non-English languages.

Table 1 outlines the main data from the eligible studies. Twelve studies reported the total lag time from the onset of symptoms to the initiation of DMARD therapy. The weighted average of median lag time of 5,512 patients from the onset of symptoms to therapy was 11.79 months with a range of 3.6-24.0 months (Figure 2). ${ }^{16-26}$

Lag1 data were also available from 12 studies on a total of 6,055 RA patients. The weighted average of median lag time from the onset of symptoms to the first physician consultation was 3.41 months with a range of $0-5.7$ months. ${ }^{17,20,22,26-34}$

Lag2 data were available from 13 studies on a total of 34,767 RA patients. The weighted average of median lag time for RA specialist referral after consulting a physician was 2.13 months with a range of $0.5-6.6$ months. ${ }^{17,20,22,25,26,29-31,33-37}$

Lag3 data were available from 3 studies on a total of 563 RA patients. The weighted average of median lag time for the diagnosis of RA after consulting a rheumatologist was 2.91 months with a range of $0-5$ months..$^{16,17,21}$

Lag4 data were available from 5 studies on a total of 30,685 RA patients. The weighted average of median lag time for initiation of DMARD therapy after definite diagnosis of RA was 2.14 months with a range of $0-2.2$ months. ${ }^{16,17,20,24,37}$

\section{Early RA diagnosis and gaps in care}

The understanding of "early" RA is heterogeneous. Two of 3 rheumatologists use the term "early" for symptoms shorter than 3 months. The vast majority of the rheumatologists surveyed regard symptom duration of $<3$ months as early. ${ }^{38}$

Evidence is accumulating that very early RA (within the first 12 weeks) may be an immunopathologically distinct phase of disease. Thus, a "window of opportunity" may exist during which introducing DMARDs may have different effects than treatment at a later date, including prevention of erosions and possibly complete switching off of the disease. ${ }^{39}$

It was found that the strongest predictor of improvements in disease activity (according to the American College of Rheumatology definition) was shorter disease duration at the start of treatment. ${ }^{39}$

Gaps in care begin with the person's recognition of the symptoms and the action of visiting a family physician (FP). If RA is suspected, the FP refers the person to a rheumatologist who provides diagnosis and prescribes appropriate 
Table I Characteristics of the studies providing data relevant to our analysis

\begin{tabular}{|c|c|c|c|c|c|c|}
\hline Study & Country & $\begin{array}{l}\text { No. of } \\
\text { patients }\end{array}$ & $\begin{array}{l}\text { Symptoms to first } \\
\text { physician visit (Lag I; } \\
\text { months) }\end{array}$ & $\begin{array}{l}\text { Initial visit to } \\
\text { rheumatology } \\
\text { referral (Lag2; } \\
\text { months) }\end{array}$ & $\begin{array}{l}\text { Referral to } \\
\text { diagnosis } \\
\text { (Lag3; } \\
\text { months) }\end{array}$ & $\begin{array}{l}\text { Diagnosis to DMARD } \\
\text { initiation (Lag4; months) }\end{array}$ \\
\hline \multirow[t]{3}{*}{ Cho et $\mathrm{al}^{27}$} & \multirow[t]{3}{*}{ Korea } & \multirow[t]{3}{*}{98} & 2 & & & \\
\hline & & & \multicolumn{2}{|l|}{5.75} & & \\
\hline & & & \multicolumn{3}{|l|}{42} & \\
\hline Irvine et $\mathrm{al}^{28}$ & UK & 74 & 4 & & & \\
\hline Sokka and Pincus ${ }^{47}$ & USA & 232 & 5.1 & & & \\
\hline \multirow[t]{2}{*}{ Ayas and $\mathrm{Nur}^{36}$} & \multirow[t]{2}{*}{ UK } & \multirow[t]{2}{*}{269} & \multicolumn{2}{|l|}{6} & & \\
\hline & & & & 3 & & \\
\hline Lacaille et $\mathrm{al}^{37}$ & Canada & 27,710 & & 2.2 (IQR 0.7-6.4) & & $\begin{array}{l}30 \% \text { prior to or at the time of } \\
\text { diagnosis and } 70 \% \text { within } 2.2 \\
\text { months after diagnosis } \\
\text { (IQR } 0.76-6.6 \text { ) }\end{array}$ \\
\hline Clemente et a $\left.\right|^{19}$ & Spain & 865 & \multicolumn{4}{|l|}{14} \\
\hline Feldman et $\mathrm{al}^{48}$ & Canada & 13,237 & \multicolumn{2}{|l|}{2.6 (IQR 0.9-7.6) } & & \\
\hline \multirow[t]{2}{*}{ Kumar et al ${ }^{29}$} & \multirow[t]{2}{*}{ UK } & \multirow[t]{2}{*}{169} & $\begin{array}{l}3.25 \text { in RF-positive } \\
\text { patients compared to } I \text { in } \\
\text { RF-negative patients }\end{array}$ & 0.5 (IQR 0.25-2.5) & & \\
\hline & & & 5.75 (IQR 3-I3.5) & & & \\
\hline \multirow[t]{2}{*}{ Badsha et $\mathrm{al}^{49}$} & \multirow{2}{*}{$\begin{array}{l}\text { United Arab } \\
\text { Emirates }\end{array}$} & \multirow[t]{2}{*}{100} & \multicolumn{3}{|l|}{14.4 (average) } & \\
\hline & & & \multicolumn{4}{|l|}{19.2 (average) } \\
\hline Ankjær-Jensen $^{50}$ & Denmark & NA & & & 5.6 & \\
\hline \multirow[t]{3}{*}{ Kiely et $\mathrm{al}^{26}$} & \multirow[t]{3}{*}{ UK and Ireland } & \multirow[t]{3}{*}{808} & 4 (IQR 2-9) & I (IQR I-2) & I (IQR 0-2) & \\
\hline & & & \multicolumn{2}{|l|}{5 (IQR 3-12) } & & \\
\hline & & & \multicolumn{4}{|l|}{8 (IQR 4-I3) } \\
\hline Koh et $\mathrm{al}^{51}$ & Singapore & 386 & $8.4 \pm 9.0$ & & & \\
\hline \multirow[t]{2}{*}{ Fathi et al ${ }^{52}$} & Egypt & 196 & $24.1 \pm 44.2$ & & & \\
\hline & & & $31.5 \pm 50.0$ & & & \\
\hline van der Linden & The & 598 & 0.6 & 2 & & \\
\hline et $\mathrm{al}^{30}$ & Netherlands & & 3.4 & & & \\
\hline $\begin{array}{l}\text { Robinson and } \\
\text { Taylor }{ }^{46}\end{array}$ & New Zealand & 128 & $\begin{array}{l}\text { I.7 (IQR 0.93-3.17) in urge } \\
\text { semi-urgent patients }\end{array}$ & nt patients; 3.8 (IQR I. & $-11)$ in & \\
\hline & & & $\begin{array}{l}\text { 4.I (IQR 2.7-8.I) in urgent } \\
\text { semi-urgent patients }\end{array}$ & patients; 6.9 (IQR 4.6- & $8.8)$ in & \\
\hline & & & 4 (IQR 3-7.23) in urgent $p$ & tients; 7.3 (IQR 4.4-18) & in semi-urgent & patients \\
\hline Blanco et $\mathrm{al}^{53}$ & Spain & 915 & $6.3 \pm 11.3$ & & & $2.3 \pm 10.2$ \\
\hline & & & & & $4.0 \pm 13.5$ & \\
\hline Rodríguez-Polanco & Venezuela & 272 & 13 & & & 1 \\
\hline et $\mathrm{al}^{16}$ & & & 5.5 & & 5 & \\
\hline & & & 24 & & & \\
\hline Jamal et al ${ }^{17}$ & Canada & 204 & 3.03 (IQR I.02-8.04) & 2.0 I (IQR I.02-4.0I) & 0.0 & 0.0 (IQR 0.00-0.99) \\
\hline & & & 6.35 (IQR 3.29-12.0I) & & & \\
\hline Raza et al ${ }^{54}$ & Pan Europe & 482 & 6 (IQR 3.3-I6.55) & & & \\
\hline Verschueren et $\mathrm{al}^{55}$ & Belgium & 182 & 5.5 (IQR 3.08-9.75) & & & \\
\hline Zafar et a $\left.\right|^{56}$ & United Arab & 100 & 7.8 & & & \\
\hline & Emirates & & 12.5 & & & \\
\hline Nanji et al ${ }^{34}$ & Canada & 151 & 4 & 0.8 & & \\
\hline & & & 5 & & & \\
\hline Kimura et $\mathrm{al}^{31}$ & Japan & 296 & 2.2 (IQR $0.1 \mathrm{I}-\mathrm{I})$ & I.25 (IQR 0.I-0.67) & & \\
\hline & & & 6.72 (IQR 0.36-2.3।3) & & & \\
\hline
\end{tabular}


Table I (Continued)

\begin{tabular}{|c|c|c|c|c|c|c|}
\hline Study & Country & $\begin{array}{l}\text { No. of } \\
\text { patients }\end{array}$ & $\begin{array}{l}\text { Symptom to first } \\
\text { physician visit (Lag I; } \\
\text { months) }\end{array}$ & $\begin{array}{l}\text { Initial visit to } \\
\text { rheumatology } \\
\text { referral (Lag2; } \\
\text { months) }\end{array}$ & $\begin{array}{l}\text { Referral to } \\
\text { diagnosis } \\
\text { (Lag3; } \\
\text { months) }\end{array}$ & $\begin{array}{l}\text { Diagnosis to DMARD } \\
\text { initiation (Lag4; months) }\end{array}$ \\
\hline \multirow{3}{*}{$\begin{array}{l}\text { Gómez Caballero } \\
\text { et a }\left.\right|^{57}\end{array}$} & \multirow[t]{3}{*}{ Spain } & \multirow[t]{3}{*}{183} & \multicolumn{3}{|l|}{$11.3 \pm 13.2$} & \\
\hline & & & \multicolumn{2}{|l|}{$10.2 \pm 12.7$} & & \\
\hline & & & \multicolumn{4}{|l|}{$1 \mathrm{I} .1 \pm 12.8$} \\
\hline \multirow[t]{3}{*}{ Natalia et al ${ }^{32}$} & \multirow[t]{3}{*}{ Argentina } & \multirow[t]{3}{*}{316} & I (IQR 0.3-2) & & \multicolumn{2}{|c|}{0.8 (IQR 0.2-12.17) } \\
\hline & & & \multicolumn{2}{|l|}{3 (IQR I.2-7) } & & \\
\hline & & & \multicolumn{4}{|l|}{5.5 (IQR I-12.17) } \\
\hline \multirow[t]{4}{*}{ Doornum et a ${ }^{25}$} & \multirow[t]{4}{*}{ Australia } & \multirow[t]{3}{*}{135} & \multicolumn{4}{|l|}{5.4 (IQR 2.9-I0.8) } \\
\hline & & & & I.I (IQR 0.3-I.8) & & \\
\hline & & & & \multicolumn{3}{|l|}{0} \\
\hline & & & \multicolumn{2}{|c|}{3.26 (same research, but no IQR) } & & \\
\hline Fautrel et al ${ }^{33}$ & France & 813 & 0.5 & 1 & & \\
\hline \multirow[t]{2}{*}{ De Cock et al $\left.\right|^{* 58}$} & \multirow[t]{2}{*}{ Belgium } & \multirow[t]{2}{*}{69} & & & & 0.25 (IQR I) \\
\hline & & & \multicolumn{4}{|l|}{6.75 (IQR 29.5) } \\
\hline \multirow{2}{*}{$\begin{array}{l}\text { Zonana Nacach } \\
\text { et } \mathrm{al}^{22}\end{array}$} & \multirow[t]{2}{*}{ Mexico } & \multirow[t]{2}{*}{98} & 2.9 & 6.6 & & \\
\hline & & & \multicolumn{4}{|l|}{9.9} \\
\hline Gibson et a $\left.\right|^{59}$ & Australia & 177 & \multicolumn{3}{|l|}{44.4} & \\
\hline Widdifield et al ${ }^{35}$ & Canada & 1,086 & & 2 & & \\
\hline \multirow[t]{2}{*}{ De Cock et a ${ }^{23}$} & \multirow[t]{2}{*}{ Belgium } & \multirow[t]{2}{*}{156} & 2.5 (IQR) & 1.75 (IQR) & & 0.25 (IQR) \\
\hline & & & \multicolumn{4}{|l|}{5.75 (IQR) } \\
\hline $\begin{array}{l}\text { Sørensen and } \\
\text { Hetland }{ }^{60}\end{array}$ & Denmark & $|3,72|$ & \multicolumn{3}{|l|}{4} & \\
\hline Benaglio et $\mathrm{al}^{61}$ & Italy & 513 & 3.5 & & & \\
\hline Ješe et $\mathrm{al}^{21}$ & Slovenia & 87 & 2.47 (IQR I.I-6.3) & 3.17 (IQR I.5-6.5) & & \\
\hline & & & 3.6 (IQR I.9-6.9) & & & \\
\hline Widdifield et a ${ }^{20}$ & Canada & 2,430 & 5.7 & 2.2 & & 1.8 \\
\hline & & & 10.9 & & & \\
\hline & & & $>13.3$ & & & \\
\hline Hussain et $\mathrm{al}^{14}$ & Saudi Arabia & 250 & $6.2 \pm 5.5$ & $30.2 \pm 16.0$ & & \\
\hline
\end{tabular}

Notes: Lag times are median values in month. Values are also presented as mean \pm SD wherever available. *The article had provided enough data to calculate IQR values. Abbreviation: IQR, interquartile range; DMARD, disease-modifying antirheumatic drug; RF, rheumatoid factor; NA, not available.

Type of Lag time, number of studies (minimum - maximum)

-L- Lag1: 12 studies; 6,055 patients (3.41; 0-5.7)

- Lag2: 13 studies; 34,767 patients $(2.13 ; 0.5-6.6)$

-- Lag3: 13 studies; 563 patients $(2.91 ; 0-5)$

-1- Lag4: 5 studies; 30,685 patients $(2.14 ; 0-2.2)$

-1- Total: 12 studies; 5,512 patients $(11.79 ; 3.6-24)$

$-24-14$

Weighted average of reported median log time
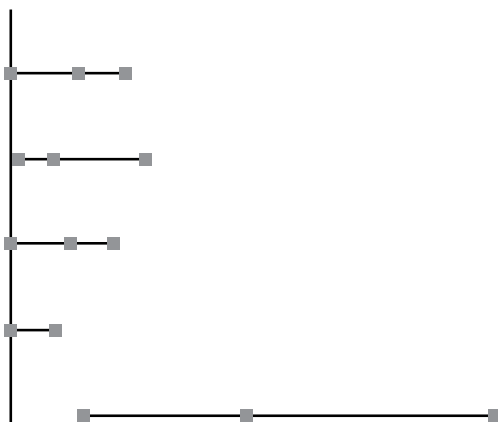

$-4$

6

16

Median duration (months)

Figure $\mathbf{2}$ Reported lag times in rheumatoid arthritis patients. 
medications. Next, the person will be periodically assessed by a rheumatologist.

Studies performed in the past 2 decades which evaluate the onset of DMARDs treatment in patients with early RA, performed in the USA, Spain, Canada, the UK, the Middle East, and in European countries, show that the mean time since the onset of disease and the onset of disease-modifying antirheumatic treatment ranges from 6 to 18 months. ${ }^{22}$ This indicates that the diagnosis of RA after the onset of symptoms is delayed, and therefore, the objective of starting treatment early is not achieved in most of the cases.

\section{Causes of delay}

Delay is probably due to a combination of patient-related and physician-related factors. We reviewed 17 papers and analyzed factors contributing to the delay in care for RA patients (Table 2).

The results of a recent study published in 2014 evaluating the time since the beginning of disease and the visit to the FP, the time since this and the referral to the rheumatologist, and the time to onset of DMARD treatment, ${ }^{22}$ showed that only in $19 \%$ of patients, DMARDs were started in the first 3 months after disease onset and that the delay in the prescription of DMARDs was mainly due to the delay in referral from family medicine to the rheumatologist.

In addition to the assumption of incompetency and poor knowledge, a qualitative research among osteoarthritis (OA) and RA patients in Germany, France, Spain, UK, and Italy revealed that for the majority of interviewed patients, their general practitioner visit is rated as disappointing due to poor communication and a focus merely on pain control. The journey that a patient undergoes before seeking medical advice is frequently long and emotionally exhausting. ${ }^{40}$

Delay in the diagnosis and management of RA may stem from slow diagnosis by physicians rather than postponed medical consultation by patients. This may be because patients with RA often do not seek the advice of rheumatologists at the onset of their symptoms and non-rheumatologists fail to refer RA patients to rheumatologists soon enough. In Saudi Arabia, although patients consulted with physicians at a mean of 7 months after the onset of RA symptoms, very few subjects initially sought a consultation with rheumatologists, who were ultimately responsible for diagnosing most RA patients. ${ }^{14}$ It is thus believed that delayed specialist

Table 2 Factors associated with delays in the diagnosis and treatment of rheumatoid arthritis

\begin{tabular}{|c|c|c|c|c|}
\hline Reference & $\begin{array}{l}\text { Location; } \\
\text { patients } \\
\text { (research time) }\end{array}$ & Factor studied & Findings & Author recommendation \\
\hline Lard et $\mathrm{al}^{62}$ & $\begin{array}{l}N / A ; 142 F+82 \\
M(1993-1999)\end{array}$ & I. Gender & $\begin{array}{l}\text { I. More delay in women as compared to } \\
\text { men (median of } 93 \text { vs } 58 \text { days) }\end{array}$ & $\begin{array}{l}\text { GPs should be made aware that } \\
\text { early detection and early referral of } \\
\text { patients with RA are crucial for early } \\
\text { treatment }\end{array}$ \\
\hline $\begin{array}{l}\text { Xibillé- } \\
\text { Friedmann } \\
\text { et al }{ }^{63}\end{array}$ & $\begin{array}{l}\text { México; } 530 \\
(2002)\end{array}$ & I. PCP & $\begin{array}{l}\text { I. Only } 20 \% \text { of the PCP referrals are } \\
\text { confirmed as RA } \\
\text { 2. PCPs do not utilize the laboratory and } \\
\text { X-ray technologies effectively, leading to } \\
\text { a delay in accurate diagnosis } \\
\text { 3. Even diagnosed cases were referred with } \\
\text { a huge delay of } 3 \text { years }\end{array}$ & $\begin{array}{l}\text { A vigorous effort in educating PCP is } \\
\text { needed to achieve early diagnosis and } \\
\text { referral of RA cases }\end{array}$ \\
\hline Neill et al ${ }^{64}$ & $\begin{array}{l}\text { Ireland; N/A } \\
(2011)\end{array}$ & I. PCP & $\begin{array}{l}\text { I. PCPs lack knowledge on diagnosis and } \\
\text { importance of timely treatment of RA } \\
\text { 2. Diagnostic uncertainty and shortage of } \\
\text { rheumatologists lead to delay in referral } \\
\text { from PCPs }\end{array}$ & $\begin{array}{l}\text { Diagnostics facility and training of } \\
\text { PCPs }\end{array}$ \\
\hline $\begin{array}{l}\text { Widdifield } \\
\text { et al }{ }^{65}\end{array}$ & $\begin{array}{l}\text { Canada; 27,I } 27 \\
\text { (1997-2008) }\end{array}$ & $\begin{array}{l}\text { I. Age } \\
\text { 2. SES } \\
\text { 3. Having a male PCP } \\
\text { 4. Measures of poor } \\
\text { access }\end{array}$ & $\begin{array}{l}\text { I. Increasing age, lower SES, and having } \\
\text { a male PCP limits timely access to } \\
\text { rheumatologists } \\
\text { 2. Measures of poor access (poor } \\
\text { continuity of primary care, density, and } \\
\text { proximity to rheumatologists) negatively } \\
\text { impacted rates of encounters with a } \\
\text { rheumatologist }\end{array}$ & $\begin{array}{l}\text { Proactive, tailored approaches are } \\
\text { needed to provide rheumatology care } \\
\text { to such populations }\end{array}$ \\
\hline Panchal ${ }^{66}$ & UK; 189 (2012) & I. Ethnicity & $\begin{array}{l}\text { I. Black minorities experienced more delay } \\
\text { as compared to Caucasians }\end{array}$ & $\begin{array}{l}\text { There may be a range of ethnically } \\
\text { specific culturally centered reasons for } \\
\text { such delay }\end{array}$ \\
\hline
\end{tabular}


Table 2 (Continued)

\begin{tabular}{|c|c|c|c|c|}
\hline Reference & $\begin{array}{l}\text { Location; } \\
\text { patients } \\
\text { (research time) }\end{array}$ & Factor studied & Findings & Author recommendation \\
\hline Zafar et al ${ }^{56}$ & $\begin{array}{l}\text { United Arab } \\
\text { Emirates; N/A } \\
(2006)\end{array}$ & I. Public awareness & $\begin{array}{l}\text { I. A positive and statistically significant } \\
\text { reduction in the lag time to both } \\
\text { diagnosis and the initiation of DMARD } \\
\text { therapy was achieved in } 5 \text { years of } \\
\text { launching a public awareness campaign }\end{array}$ & $\begin{array}{l}\text { This difference in lag time may in part } \\
\text { be attributed to the inception of the } \\
\text { patient support groups, coupled with } \\
\text { the general drive toward increasing } \\
\text { public awareness about RA }\end{array}$ \\
\hline $\begin{array}{l}\text { Delaurier } \\
\text { et al }{ }^{67}\end{array}$ & $\begin{array}{l}\text { Canada; N/A } \\
(2009-2010)\end{array}$ & $\begin{array}{l}\text { I. Rheumatologist } \\
\text { appointment }\end{array}$ & $\begin{array}{l}\text { I. Most patients with RA are still } \\
\text { not receiving an appointment to a } \\
\text { rheumatologist in a timely manner }\end{array}$ & $\begin{array}{l}\text { Effective triage tools to decrease these } \\
\text { delays should be instituted }\end{array}$ \\
\hline Grygielska $^{68}$ & $\begin{array}{l}\text { Poland; I,000 } \\
(2009-2010)\end{array}$ & $\begin{array}{l}\text { I. Geographical } \\
\text { factor } \\
\text { 2. Gender } \\
\text { 3. Age }\end{array}$ & $\begin{array}{l}\text { I. Inhabitants of rural area are diagnosed } \\
\text { earlier than inhabitants of big cities } \\
\text { 2. Men were diagnosed earlier than women } \\
\text { 3. Respondents with first symptoms in } \\
\text { younger age were diagnosed later than } \\
\text { older patients }\end{array}$ & \\
\hline Molina et $\mathrm{a}^{69}$ & USA; I,209 (2014) & I. SES & $\begin{array}{l}\text { I. Lower SES leads to significant delay in } \\
\text { DMARD treatment ( } 8.5 \text { vs } 6.1 \text { years for } \\
\text { middle and upper SES patients), both of } \\
\text { which were independently associated } \\
\text { with worse clinical outcomes }\end{array}$ & \\
\hline Barnabe et $\mathrm{a}^{70}$ & $\begin{array}{l}\text { Canada; I, I } 42 \\
(2012)\end{array}$ & $\begin{array}{l}\text { I. Severity of disease } \\
\text { activity } \\
\text { 2. Serology results } \\
\text { (anti-CCP } \\
\text { antibody-positive } \\
\text { patients) } \\
\text { 3. Lower income } \\
\text { levels } \\
\text { 4. Ethnicity } \\
\text { 5. Underlying } \\
\text { comorbidities }\end{array}$ & $\begin{array}{l}\text { I. Higher number of swollen joints, } \\
\text { elevated acute-phase reactants, and } \\
\text { worse patient global scores decrease } \\
\text { time to diagnosis } \\
\text { 2. Positive serology results are associated } \\
\text { with delays in time to diagnosis in } \\
\text { multivariate analysis. The reasons for } \\
\text { this unanticipated finding are unclear. } \\
\text { One potential reason is that some triage } \\
\text { units may delay assigning a priority to } \\
\text { the patient for an appointment until } \\
\text { the serology results are available, } \\
\text { which will delay the time to diagnosis. } \\
\text { In addition, availability of anti-CCP } \\
\text { testing is restricted in some regions of } \\
\text { Canada, despite its utility in diagnosis and } \\
\text { prognosis of RA. } \\
\text { 3. Patients with lower income levels are at } \\
\text { risk of delays in diagnosis } \\
\text { 4. Did not find any evidence of } \\
\text { discrimination in time to diagnosis } \\
\text { based on ethnicity or underlying health } \\
\text { comorbidities }\end{array}$ & \\
\hline Sung et $\mathrm{al}^{71}$ & Korea; $7 \mid 4(2014)$ & $\begin{array}{l}\text { I. Age } \\
\text { 2. Education } \\
\text { 3. Income } \\
\text { 4. Disease activity }\end{array}$ & $\begin{array}{l}\text { I. Older onset age, higher education } \\
\text { level and higher income lead to early } \\
\text { diagnosis } \\
\text { 2. DAS28 remained similar but hand joints } \\
\text { were more eroded in delayed diagnosis }\end{array}$ & \\
\hline $\begin{array}{l}\text { Widdifield } \\
\text { et } \mathrm{al}^{72}\end{array}$ & $\begin{array}{l}\text { Canada; } 2,430 \\
(2015)\end{array}$ & I. PCP & $\begin{array}{l}\text { I. Approximately I in } 3 \text { PCP referrals to } \\
\text { rheumatologists were referred for a } \\
\text { systemic inflammatory rheumatic disease }\end{array}$ & $\begin{array}{l}\text { Understanding the referral patterns } \\
\text { of PCPs can identify opportunities to } \\
\text { improve PCP management of patients } \\
\text { prior to rheumatology referral }\end{array}$ \\
\hline
\end{tabular}


Table 2 (Continued)

\begin{tabular}{|c|c|c|c|c|}
\hline Reference & $\begin{array}{l}\text { Location; } \\
\text { patients } \\
\text { (research time) }\end{array}$ & Factor studied & Findings & Author recommendation \\
\hline Simons et $\mathrm{al}^{73}$ & $\begin{array}{l}\text { UK; } 32 \mathrm{~F}+6 \mathrm{M} \\
(20 \mathrm{I} 5)\end{array}$ & $\begin{array}{l}\text { I. Perceived causes } \\
\text { of symptoms } \\
\text { 2. Presentation, } \\
\text { location, and } \\
\text { experience of } \\
\text { symptoms } \\
\text { 3. Perceived impact } \\
\text { of symptoms on } \\
\text { daily life } \\
\text { 4. Self-management } \\
\text { of symptoms } \\
\text { 5. GP-related drivers } \\
\text { and barriers }\end{array}$ & $\begin{array}{l}\text { I. Factors prompting GP consultation } \\
\text { included: } \\
\text { - a sudden and severe symptom onset } \\
\text { - symptoms resistant to self-management } \\
\text { strategies } \\
\text { - symptoms not easing } \\
\text { - symptoms disrupting daily activities } \\
\text { - the perception that symptoms were } \\
\text { unusual and could not be explained } \\
\text { 2. Numbers of patients were trying to } \\
\text { identify external causative factors, or felt } \\
\text { that joint pain and stiffness were simply } \\
\text { part of getting older and as a result they } \\
\text { would delay or avoid seeking medical } \\
\text { attention. Others mentioned "knocks" } \\
\text { and other injuries as a possible cause, } \\
\text { specifically when experiencing symptoms } \\
\text { in a single joint. They would delay } \\
\text { help-seeking if they suspected injury as a } \\
\text { causal factor } \\
\text { 3. RA patients interviewed within a year } \\
\text { of diagnosis, described using over-the- } \\
\text { counter medications prior to, or instead } \\
\text { of, seeking medical advice or while } \\
\text { awaiting a formal diagnosis }\end{array}$ & \\
\hline Molina $^{74}$ & $\begin{array}{l}\text { USA; I,209 } \\
(1996-2009)\end{array}$ & $\begin{array}{l}\text { I. Potential health } \\
\text { barriers } \\
\text { 2. Distance to the } \\
\text { rheumatologist } \\
\text { 3. SES }\end{array}$ & $\begin{array}{l}\text { I. All the } 3 \text { factors were independently } \\
\text { associated with disease activity, joint } \\
\text { damage, and physical disability } \\
\text { 2. Distance was not significantly correlated } \\
\text { with DMARD lag and was inversely } \\
\text { associated with these clinical measures, } \\
\text { suggesting that patients who live closer } \\
\text { to the rheumatologist have more severe } \\
\text { RA. This result was unexpected } \\
\text { 3. On average, patients with lower SES } \\
\text { waited } 8.5 \text { years after the onset of RA } \\
\text { symptoms to begin DMARD treatment, } \\
\text { compared to those in the middle and } \\
\text { upper SES tertiles who waited } 6.16 \\
\text { years }\end{array}$ & \\
\hline $\begin{array}{l}\text { Peerboom } \\
\text { et } \mathrm{al}^{75}\end{array}$ & Belgium; 94 (2015) & $\begin{array}{l}\text { I. Pain } \\
\text { 2. PCP }\end{array}$ & $\begin{array}{l}\text { I. Pain is the foremost related symptom at } \\
\text { the onset and the most important reason } \\
\text { to visit the GP, accelerating diagnosis } \\
\text { 2. } 25 \% \text { of patients needed }>5 \text { visits before } \\
\text { ERA was detected }\end{array}$ & \\
\hline Mølbæk et $\mathrm{al}^{76}$ & $\begin{array}{l}\text { Denmark; II } \\
(20 \mid 4)\end{array}$ & $\begin{array}{l}\text { I. Nature and } \\
\text { severity of } \\
\text { symptoms }\end{array}$ & $\begin{array}{l}\text { I. When symptoms were obvious to } \\
\text { patients, there was a shorter delay } \\
\text { between symptom onset and contacting } \\
\text { their GP. In cases where symptoms } \\
\text { gradually worsened or were difficult to } \\
\text { interpret, there was a longer delay } \\
\text { 2. Participants with a high degree of } \\
\text { body awareness appeared to be good } \\
\text { at detecting when something was not } \\
\text { normal, and they responded quickly to } \\
\text { their symptoms }\end{array}$ & \\
\hline
\end{tabular}


Table 2 (Continued)

\begin{tabular}{|c|c|c|c|c|}
\hline Reference & $\begin{array}{l}\text { Location; } \\
\text { patients } \\
\text { (research time) }\end{array}$ & Factor studied & Findings & Author recommendation \\
\hline & & & $\begin{array}{l}\text { 3. For those who regarded the doctor as } \\
\text { a resource to which they were entitled } \\
\text { and who were not worried about getting } \\
\text { a diagnosis, there was a shorter delay } \\
\text { 4. Diffuse symptoms seemed to confuse } \\
\text { GPs and can contribute to physician } \\
\text { delay in the investigation process } \\
\text { 5. The presence of other diseases can } \\
\text { result in a prolonged period before } \\
\text { referral to a rheumatologist } \\
\text { 6. The results showed that the greater } \\
\text { the awareness of the patient's body, the } \\
\text { better the disease recognition, the fewer } \\
\text { barriers to contacting the GP and the } \\
\text { shorter the delay in doing so }\end{array}$ & \\
\hline Pratt et $\mathrm{a}^{77}$ & $\begin{array}{l}\text { UK; I73 (20II- } \\
2014)\end{array}$ & $\begin{array}{l}\text { I. Serology results } \\
\text { (anti-CCP } \\
\text { antibody-positive } \\
\text { patients) }\end{array}$ & $\begin{array}{l}\text { I. Retrospective analysis to determine } \\
\text { whether time to treatment following } \\
\text { symptom onset differs between RA } \\
\text { patients according to autoantibody status } \\
\text { 2. ACPA+/RF+ patients experienced } \\
\text { significantly longer symptom duration } \\
\text { before DMARD initiation } \\
\text { 3. This accounted for delays in their } \\
\text { presentation to primary care following } \\
\text { symptom onset } \\
\text { 4. In contrast, ACPA-/RF- patients were } \\
\text { significantly more likely to experience } \\
\text { delays in DMARD initiation after } \\
\text { presenting to secondary care } \\
\text { 5. Causes of treatment delays in early RA } \\
\text { differ according to patients' autoantibody } \\
\text { status }\end{array}$ & \\
\hline Hussain et $\mathrm{al}^{14}$ & $\begin{array}{l}\text { Saudi Arabia; } 250 \\
(2016)\end{array}$ & $\begin{array}{l}\text { I. Early referral to } \\
\text { rheumatology } \\
\text { 2. Presence of early } \\
\text { symptoms (hand/ } \\
\text { wrist involvement, } \\
\text { fatigue) } \\
\text { 3. Geographic } \\
\text { distribution }\end{array}$ & $\begin{array}{l}\text { I. Nonrheumatologists offered diagnoses } \\
\text { in } 24.4 \% \text { of cases, while rheumatologists } \\
\text { diagnosed } 75.6 \% \\
\text { 2. The absence of early hand/wrist } \\
\text { involvement and fatigue were associated } \\
\text { with delayed RA diagnosis (long } \\
\text { lag2; } p<0.01) \text {. Moreover, geographic } \\
\text { distribution influenced RA diagnosis, } \\
\text { with rural patients experiencing a greater } \\
\text { delay than urban patients }(p<0.000 I)\end{array}$ & $\begin{array}{l}\text { RA diagnosis can be accelerated } \\
\text { by encouraging early referral to } \\
\text { rheumatologists }\end{array}$ \\
\hline
\end{tabular}

Abbreviations: M, male; F, female; N/A, not available; GP, general practitioner; RA, rheumatoid arthritis; PCP, primary care physician; SES, socioeconomic status; DMARD, disease-modifying antirheumatic drug; CCP, cyclic citrullinated peptide; DAS28, disease activity score; ERA, early rheumatoid arthritis; ACPA, anti-citrullinated protein antibody; RF, rheumatoid factor.

referrals constitute a principal reason for late diagnosis and subsequent treatment.

\section{Possible interventions}

It is necessary to implement measures that act on early diagnosis and treatment of RA, through the diffusion of knowledge relating to the disease in the general population, advertising campaigns as well as an increase in the level of knowledge regarding RA in primary care physicians.
Successful intervention is largely dependent on the availability of local programs and the coordination among the rheumatologist, the FP, and other health professionals. Moving from one level of care to the next involves a potential wait period. $^{41}$

A 2013 systematic literature review addressed and identified 3 main areas of delay to care for patients with inflammatory arthritis (IA) and potential solutions ${ }^{42}$ From the onset of symptoms to primary care, several websites provided informa- 
tion but were of varying quality and insufficient to aid early referral. At a primary care level, many guidelines emphasized the need for early referral with providing specific referral criteria. ${ }^{39,43}$ Once referred, early arthritis clinics provided a point of early access to rheumatology assessment. Triage systems, including triage clinics, helped prioritizing clinic appointments for patients with IA. Use of referral forms standardized the information required, further optimizing the triage process.

Guidelines for early referral are needed. ${ }^{38}$ Clinical criteria would facilitate early referral of the patient with suspected RA to a rheumatologist for definitive diagnosis and initiation of DMARD treatment. In a recently published study by Almoallim et al, ${ }^{44}$ we have validated the variables that may aid in the design of referral criteria. These are based on musculoskeletal examination techniques to assess the presence of arthritis by primary care physicians in "target" joints; wrists, second and third metacarpophalangeals, and third proximal interphalangeal joints. ${ }^{45}$ This is in addition to positive rheumatoid factor and anti-citrullinated protein antibody (anti-cyclic citrullinated peptide).

Key points of the referral criteria were formed based on literature review. Clinical evidence strongly supports the observations that rapid referral to a rheumatologist is advised when RA is suspected, which may be supported by the presence of any of the following: persistent joint swelling in more than 1 joint, early morning stiffness $\geq 30$ minutes, or involvement of metacarpophalangeal or metatarsophalangeal joints. ${ }^{39,43}$ These criteria were mainly based on experts' opinion not on validated measures as in our unpublished work. Urgent referral (ideally within 6 weeks of symptom onset) to rheumatology should then be made with a clear indication that IA (or RA) is suspected. This should be done without waiting for the results of tests such as rheumatoid factor and plain radiographs, which are often normal in the early phase of disease. ${ }^{39,43}$

All rheumatologists should make it a priority to see patients with suspected IA on an urgent basis. Triage is important to facilitate early treatment; however, rheumatologists in this service are not currently triaging suspected RA referrals with reference to known poor prognostic indicators. ${ }^{46}$ However, several interventions could improve both informative referrals and triaging of referrals to decrease time to diagnosis and treatment including public education, general practitioner education sessions with associated distribution of referral guidelines, and reminding triaging rheumatology clinicians about the available prognostic factors often present in general practitioner referrals that assist with correct triage. ${ }^{46}$

\section{Acknowledgments}

This work was supervised and funded by Alzaidi Chair of Research in Rheumatic Diseases, Umm Alqura University. The authors are grateful to Dr Soha Elmorsy, MD, PhD, Research Consultant, King Abdullah Medical City, Makkah, KSA, for statistical advice.

\section{Disclosure}

The authors certify that they have no affiliations with or involvement in any organization or entity with any financial interest or nonfinancial interest in the subject matter or materials discussed in this manuscript. The authors report no conflicts of interest in this work.

\section{References}

1. Pincus T, Callahan LF. Reassessment of twelve traditional paradigms concerning the diagnosis, prevalence, morbidity and mortality of rheumatoid arthritis. Scand J Rheumatol. 1989;18(Supp179):67-96.

2. Sherrer YS, Bloch DA, Mitchell DM, Young DY, Fries JF. The development of disability in rheumatoid arthritis. Arthritis Rheum. 1986;29(4):494-500.

3. Steiman AJ, Pope JE, Thiessen-Philbrook H, et al. Non-biologic disease-modifying antirheumatic drugs (DMARDs) improve pain in inflammatory arthritis (IA): a systematic literature review of randomized controlled trials. Rheumatol Int. 2013;33(5):1105-1120.

4. Aaltonen KJ, Virkki LM, Malmivaara A, Konttinen YT, Nordström DC, Blom M. Systematic review and meta-analysis of the efficacy and safety of existing TNF blocking agents in treatment of rheumatoid arthritis. PLoS One. 2012;7(1):e30275.

5. Pincus T. Rheumatoid arthritis: disappointing long-term outcomes despite successful short-term clinical trials. J Clin Epidemiol. 1988;41(11): 1037-1041.

6. Kushner I. Does aggressive therapy of rheumatoid arthritis affect outcome? J Rheumatol. 1989;16(1):1.

7. Harris ED Jr. Rheumatoid arthritis: pathophysiology and implications for therapy. N Engl J Med. 1990;322(18):1277-1289.

8. Anderson JJ, Wells G, Verhoeven AC, Felson DT. Factors predicting response to treatment in rheumatoid arthritis: the importance of disease duration. Arthritis Rheum. 2000;43(1):22-29.

9. Borg G, Allander E, Lund B, et al. Auranofin improves outcome in early rheumatoid arthritis. Results from a 2-year, double blind placebo controlled study. J Rheumatol. 1988;15(12):1747-1754.

10. Singh JA, Saag KG, Bridges SL Jr, et al. 2015 American College of Rheumatology Guideline for the Treatment of Rheumatoid Arthritis. Arthritis Rheumatol. 2016;68(1):1-26.

11. Jacoby R, Jayson M, Cosh J. Onset, early stages, and prognosis of rheumatoid arthritis: a clinical study of 100 patients with 11-year follow-up. Br Med J. 1973;2(5858):96.

12. Linos A, Worthington JW, O'Fallon M, Kurland LT. The epidemiology of rheumatoid arthritis in Rochester Minnesota: a study of incidence, prevalence, and mortality. Am J Epidemiol. 1980;111(1):87-98.

13. Chan KWA, Felson DT, Yood RA, Walker AM. The lag time between onset of symptoms and diagnosis of rheumatoid arthritis. Arthritis Rheum. 1994;37(6):814-820.

14. Hussain W, Noorwali A, Janoudi N, et al. From symptoms to diagnosis: an observational study of the journey of rheumatoid arthritis patients in Saudi Arabia. Oman Med J. 2016;31(1):29.

15. Hernández-García C, Vargas E, Abásolo L, et al. Lag time between onset of symptoms and access to rheumatology care and DMARD therapy in a cohort of patients with rheumatoid arthritis. J Rheumatol. 2000;27(10):2323-2328. 
16. Rodríguez-Polanco E, Al Snih S, Kuo Y-F, Millán A, Rodríguez MA. Lag time between onset of symptoms and diagnosis in Venezuelan patients with rheumatoid arthritis. Rheumatol Int. 2011;31(5):657-665.

17. Jamal S, Alibhai SM, Badley EM, Bombardier C. Time to treatment for new patients with rheumatoid arthritis in a major metropolitan city. J Rheumatol. 2011;38(7):1282-1288.

18. Zafar S, Badsha H, Mofti A, et al. Efforts to increase public awareness may result in more timely diagnosis of rheumatoid arthritis. $J$ Clin Rheumatol. 2012;18(6):279-282.

19. Clemente D, Hernández-García C, Abásolo L, et al. Reduction in time until first treatment with disease modifying treatment in patients with rheumatoid arthritis. Reumatol Clin (English Edition). 2007;3(6):245-250.

20. Widdifield J, Bernatsky S, Thorne JC, et al. Wait times to rheumatology care for patients with rheumatic diseases: a data linkage study of primary care electronic medical records and administrative data. CMAJ Open. 2016;4(2):E205-E212.

21. Ambrožič A, Gaspersic N, Hocevar A, et al. Time to disease-modifying anti-rheumatic drug treatment for new patients with rheumatoid arthritissingle center experience. Arthritis Rheumatol. 2015;67:694-695.

22. Zonana Nacach A, Campaña-Parra A, Santana-Sahagún JE. The lag time between onset of symptoms, medical encounter, and initiation of disease modifying antirheumatic drugs in patients with rheumatoid arthritis. Reumatol Clín (English Edition). 2014;10(2):131-132.

23. De Cock D, Meyfroidt S, Joly J, Van der Elst K, Westhovens R, Verschueren P. A detailed analysis of treatment delay from the onset of symptoms in early rheumatoid arthritis patients. Scand J Rheumatol. 2014;43(1):1-8.

24. De Cock D, Meyfroidt S, Joly J, Van der Elst K, Westhovens R, Verschueren P. AB0169 Type of rheumatology practice is an important determinant of treatment delay in flanders. Ann Rheum Dis. 2013;72(Suppl 3):A837.

25. Van Doornum S, Tropea J, Tacey M, Liew D. Time To Institution Of Disease Modifying Anti-rheumatic Drugs In Australian Patients With Early Rheumatoid Arthritis. Arthritis \& Rheumatism. 2013;65:S565.

26. Kiely P, Williams R, Walsh D, Young A; Early Rheumatoid Arthritis Network. Contemporary patterns of care and disease activity outcome in early rheumatoid arthritis: the ERAN cohort. Rheumatology (Oxford). 2009;48(1):57-60.

27. Cho KJ, Jang SH, Lee SK, Doh WS. Utilization characteristics of health care service for rheumatoid arthritis patients in Korea. Yonsei Med J. 1998;39(3):247-251

28. Irvine S, Munro R, Porter D. Early referral, diagnosis, and treatment of rheumatoid arthritis: evidence for changing medical practice. Ann Rheum Dis. 1999;58(8):510-513.

29. Kumar K, Daley E, Carruthers D, et al. Delay in presentation to primary care physicians is the main reason why patients with rheumatoid arthritis are seen late by rheumatologists. Rheumatology. 2007;46(9):1438-1440.

30. van der Linden MP, Le Cessie S, Raza K, et al. Long-term impact of delay in assessment of patients with early arthritis. Arthritis Rheum. 2010;62(12):3537-3546.

31. Kimura M, Yoshida K, Oshikawa H, et al. AB0308 Delay in referral and diagnosis of rheumatoid arthritis in a community medical center in japan. Ann Rheum Dis. 2013;71(Suppl 3):655.

32. Natalia Z, Christian A W, Maria FM, et al. Delay in consultation and starting disease modifying anti-rheumatic drugs in patients with rheumatoid arthritis in Argentina. How early arthritis clinics impact on health barriers? Paper presented at: 2013 ACR/ARHP Annual Meeting; October 25-30; 2013; San Diego, CA.

33. Fautrel B, Joubert J-M, Cukierman G, Laurendeau C, Gourmelen J, Fagnani F. THU0512 Rheumatoid arthritis (RA), comorbidities and biological agents uptake in France: analysis of a national claims database. Ann Rheum Dis. 2013;72(Suppl 3):A337.

34. Nanji JA, Choi M, Ferrari R, Lyddell C, Russell AS. Time to consultation and disease-modifying antirheumatic drug treatment of patients with rheumatoid arthritis - Northern Alberta Perspective. J Rheumatol. 2012;39(4):707-711.
35. Widdifield J, Bombardier C, Thorne JC, et al. A novel approach to assess wait-times to rheumatologists. Paper presented at: Arthritis and Rheumatology; 2014; Hoboken, NJ.

36. Ayas S, Nur M. Diagnosis, referral pattern and course of early arthritis: results of a special early arthritis clinic. Ann Intern Med. 1996;124:699-707.

37. Lacaille D, Anis AH, Guh DP, Esdaile JM. Gaps in care for rheumatoid arthritis: a population study. Arthritis Care Res. 2005;53(2):241-248.

38. Aletaha D, Eberl G, Nell V, Machold K, Smolen J. Practical progress in realisation of early diagnosis and treatment of patients with suspected rheumatoid arthritis: results from two matched questionnaires within three years. Ann Rheum Dis. 2002;61(7):630-634.

39. Hyrich KL. Patients with suspected rheumatoid arthritis should be referred early to rheumatology. BMJ. 2008;336(7637):215-216.

40. Diazaraque R, Scott C. [SAT0503] From me to you (without love): the arthritis patient journey from symptom onset to medical diagnosis. Ann Rheum Dis. 2009;68(Supp13):705.

41. Li LC. [SP0106] Gaps in care and research in health service delivery: using rheumatoid arthritis as a sample case. Ann Rheum Dis. 2009;68(Suppl3):33.

42. Villeneuve E, Nam JL, Bell MJ, et al. A systematic literature review of strategies promoting early referral and reducing delays in the diagnosis and management of inflammatory arthritis. Ann Rheum Dis. 2013;72(1):13-22.

43. Emery P, Breedveld F, Dougados M, Kalden J, Schiff M, Smolen J. Early referral recommendation for newly diagnosed rheumatoid arthritis: evidence based development of a clinical guide. Ann Rheum Dis. 2002;61(4):290-297.

44. Almoallim H, Janoudi N, Attar SM et al. Determining early referral criteria for patients with suspected inflammatory arthritis presenting to primary care physicians: a cross-sectional study. Open Access Rheumatology: Research and Reviews. 2017;9:81

45. Almoallim H, Attar S, Jannoudi N, et al. Sensitivity of standardised musculoskeletal examination of the hand and wrist joints in detecting arthritis in comparison to ultrasound findings in patients attending rheumatology clinics. Clin Rheumatol. 2012;31(9):1309-1317.

46. Robinson PC, Taylor WJ. Time to treatment in rheumatoid arthritis: factors associated with time to treatment initiation and urgent triage assessment of general practitioner referrals. J Clin Rheumatol. 2010;16(6):267-273.

47. Sokka T, Pincus T. Contemporary disease modifying antirheumatic drugs (DMARD) in patients with recent onset rheumatoid arthritis in a US private practice: methotrexate as the anchor drug in $90 \%$ and new DMARD in 30\% of patients. $J$ Rheumatol. 2002;29(12):2521-2524.

48. Feldman DE, Bernatsky S, Haggerty J, et al. Delay in consultation with specialists for persons with suspected new-onset rheumatoid arthritis: a population-based study. Arthritis Care Res. 2007;57(8):1419-1425.

49. Badsha H, Kong KO, Tak PP. Rheumatoid arthritis in the United Arab Emirates. Clin Rheumatol. 2008;27(6):739-742.

50. Ankjær-Jensen A. Hospital waiting time for patients with rheumatic diseases in Denmark. Ann Rheum Dis. 2009;68(Suppl3):799.

51. Koh ET, Thong B, Teh CL, et al. Differences in patients with rheumatoid arthritis presenting over time from 1960 to 2005. Ann Rheum Dis. 2009;68(Suppl 3):415.

52. Fathi N, Abda EAM, Salim ZA, Kong K, Badsha H. Rheumatoid arthritis in a cross section of Egyptian patients. Ann Rheum Dis. 2009;68(Supp13):422

53. Blanco FJ, Ballina J, Carbonell J, et al. [Descriptive study of the use of DMARD in patients with rheumatoid arthritis or persistent arthritis who start drug treatment in Spain (FIRST).] Reumatol Clin. 2011;7(2):88-93. Spanish.

54. Raza K, Stack R, Kumar K, et al. Delays in assessment of patients with rheumatoid arthritis: variations across Europe. Ann Rheum Dis. 2011;70(10):1822-1825.

55. Verschueren P, Joly J, Langenaken C, et al. Patient and disease related determinanats of the delay between symptom onset and the diagnosis of RA in a Flemish population. Ann Rheum Dis. 2011;70(Suppl3):590. 
56. Zafar S, Badsha H, Mofti A, et al. Efforts to increase public awareness may result in more timely diagnosis of rheumatoid arthritis. $J$ Clin Rheumatol. 2012;18(6):279-282.

57. Gómez Caballero ME, Corominas H, Narváez J, et al. AB1361 Diagnostic and therapeutic delay of rheumathoid artritis patients in catalonia (Spain) and their relationship with specialized healthcare units. The audit study. Ann Rheum Dis. 2013;71(Suppl 3):715.

58. De Cock D, Westhovens R, Joly J, Verschueren P. SAT0454 Determinants of delay between onset of symptoms and initiation of treatment in a belgian RA population. Ann Rheum Dis. 2013;71(Suppl 3):626.

59. Gibson KA, Luta G, Pincus T. AB0255 Delay in diagnosis from onset of symptoms by more than one year in $48 \%$ of 177 patients with rheumatic diseases, including $36 \%$ in patients with rheumatoid arthritis in Australia. Ann Rheum Dis. 2014;73(Suppl 2):888.

60. Sørensen J, Hetland ML. Diagnostic delay in patients with rheumatoid arthritis, psoriatic arthritis and ankylosing spondylitis: results from the Danish nationwide DANBIO registry. Ann Rheum Dis. 2015;74(3):e12.

61. Benaglio F, Balduzzi S, Bugatti S, Sakellariou G, Montecucco C, Caporali R. Diagnostic Delay in Early Arthritis: Ten Years-experience of a Single Center. Arthritis \& Rheumatology. 2015;67:712-714.

62. Lard LR, Huizinga TW, Hazes J, Vlieland T. Delayed referral of female patients with rheumatoid arthritis. J Rheumatol. 2001;28(10):2190-2192.

63. Xibillé-Friedmann D, Mondragón-Flores V, de la Rosa CH. Criteria used by primary care physicians for the diagnosis and referral to a rheumatologist of patients with rheumatoid arthritis. Reumatol Clín. 2006;2(5):235-238.

64. Neill LO, Kitchen J, Coughlan RJ, et al. [FRI0238] Impediments to early referral and assessment of patients with early inflammatory arthritis - a primary care perspective. Ann Rheum Dis. 2011;70(Suppl 3):423.

65. Widdifield J, Paterson MJ, Bernatsky S et al. Potential Barriers That Limit Access to Rheumatologists Among Patients with Early Rheumatoid Arthritis in a Universal Access Health Care System. Arthritis \& Rheumatism. 2012:64;S1060.

66. Panchal S, Samanta A, Moorthy A, Hayat S, Pande I, Adebajo AO, Chakravarty K. A British survey of time to presentation and treatment of rheumatoid arthritis in subjects of black and minority ethnic origin. ACR Meeting Abstracts; 2012.
67. Delaurier A, Bernatsky S, Baron M, Légaré J, Feldman DE. Wait times for rheumatology consultation: is rheumatoid arthritis prioritized? J Clin Rheumatol. 2012;18(7):341-344.

68. Grygielska J. OP0241-PARE Time to diagnosis and quality of life people with diagnosed rheumatoid arthritis in poland. Ann Rheum Dis. 2013;71(Suppl 3):137.

69. Molina E, Restrepo JF, del Rincon I, Battafarano D, Escalante A. Treatment Delays and Worse Outcomes Associated with Lower Socioeconomic Status in Rheumatoid Arthritis. Arthritis \& Rheumatology. 2014:66;S889-S890.

70. Barnabe C, Xiong J, Pope JE, et al. Factors associated with time to diagnosis in early rheumatoid arthritis. Rheumatol Int. 2014;34(1): 85-92.

71. Sung YK, Cho SK, Kim D et al. Factors Associated with Time to Diagnosis from Symptom Onset in Early Rheumatoid Arthritis Patients. Arthritis \& Rheumatology. 2014:66;S889.

72. Widdifield J, Thorne CJ, Tu K et al. Primary Care Management of Patients with Rheumatic Diseases Prior to Rheumatologist Consultation. Arthritis \& Rheumatology. 2015;67:3039-3041.

73. Simons G, Mallen CD, Kumar K, Stack RJ, Raza K. A qualitative investigation of the barriers to help-seeking among members of the public presented with symptoms of new-onset rheumatoid arthritis. $J$ Rheumatol. 2015;42(4):585-592.

74. Molina E, Del Rincon I, Restrepo JF, Battafarano DF, Escalante A. Association of socioeconomic status with treatment delays, disease activity, joint damage, and disability in rheumatoid arthritis. Arthritis Care Res. 2015;67(7):940-946.

75. Peerboom D, Van der Elst K, De Cock D, et al. The patient trajectory from symptom onset until referral to a rheumatologist. Paper presented at: European Congress of Rheumatology; June 10-13; 2015; 2015; Rome.

76. Mølbæk K, Hørslev Petersen K, Primdahl J. Diagnostic delay in rheumatoid arthritis: a qualitative study of symptom interpretation before the first visit to the doctor. Musculoskeletal care. 2016;14(1):26-36.

77. Pratt AG, Lendrem D, Hargreaves B, Aslam O, Galloway JB, Isaacs JD. Components of treatment delay in rheumatoid arthritis differ according to autoantibody status: validation of a single-centre observation using national audit data. Rheumatology. 2016:55(10):1843-1848.
Open Access Rheumatology: Research and Reviews

\section{Publish your work in this journal}

Open Access Rheumatology: Research and Reviews is an international, peerreviewed, open access journal publishing original research, reports, editorials, reviews and commentaries on all aspects of clinical and experimental rheumatology in the clinic and laboratory including the following topics: Pathology, pathophysiology of rheumatological diseases; Investigation, treatment and

\section{Dovepress}

management of rheumatological diseases; Clinical trials and novel pharmacologi$\mathrm{cal}$ approaches for the treatment of rheumatological disorders. The manuscript management system is completely online and includes a very quick and fair peer-review system, which is all easy to use. Visit http://www.dovepress.com/ testimonials.php to read real quotes from published authors. 